\title{
ARTICLE
}

Received 22 Jul 2014 | Accepted 19 Sep 2014 | Published 4 Nov $2014 \quad$ DOl: 10.1038/ncomms6328

\section{Tracing carbonate-silicate interaction during subduction using magnesium and oxygen isotopes}

Shui-Jiong Wang ${ }^{1,2}$, Fang-Zhen Teng ${ }^{2} \&$ Shu-Guang $\mathrm{Li}^{1,3}$

Subduction of carbonates and carbonated eclogites into the mantle plays an important role in transporting carbon into deep Earth. However, to what degree isotopic exchanges occur between carbonate and silicate during subduction remains unclear. Here we report $\mathrm{Mg}$ and $\mathrm{O}$ isotopic compositions for ultrahigh pressure metamorphic marbles and enclosed carbonated eclogites from China. These marbles include both calcite- and dolomite-rich examples and display similar $\mathrm{O}$ but distinct $\mathrm{Mg}$ isotopic signatures to their protoliths. Their $\delta^{26} \mathrm{Mg}$ values vary from -2.508 to $-0.531 \%$, and negatively correlate with $\mathrm{MgO} / \mathrm{CaO}$ ratios, unforeseen in sedimentary carbonates. Carbonated eclogites have extremely heavy $\delta^{18} \mathrm{O}$ (up to $+21.1 \%$ ) and light $\delta^{26} \mathrm{Mg}$ values (down to $-1.928 \%$ in garnet and $-0.980 \%$ in pyroxene) compared with their protoliths. These unique $\mathrm{Mg}-\mathrm{O}$ isotopic characteristics reflect differential isotopic exchange between eclogites and carbonates during subduction, making coupled $\mathrm{Mg}$ and $\mathrm{O}$ isotopic studies potential tools for tracing deep carbon recycling.

\footnotetext{
${ }^{1}$ State Key Laboratory of Geological Processes and Mineral Resources, China University of Geosciences, Beijing 100083, China. ${ }^{2}$ Isotope Laboratory, Department of Earth and Space Sciences, University of Washington, Seattle, Washington 98195, USA. ${ }^{3}$ CAS Key Laboratory of Crust-Mantle Materials and Environments, School of Earth and Space Sciences, University of Science and Technology of China, Hefei, Anhui 230026, China. Correspondence and requests for materials should be addressed to S.-J.W. (email: sxw057@gmail.com) or to F.-Z.T. (emai: fteng@u.washington.edu).
} 
D eep carbon recycling plays a key role in the global carbon cycle by modulating the $\mathrm{CO}_{2}$ budget of the Earth's atmosphere over geologic timescales ${ }^{1,2}$. Among different subducted lithologies, carbonates and carbonated eclogites are of particular importance in transporting carbon from Earth's surface into its interior ${ }^{3-6}$. As a subducting slab descends, some fractions of the carbon carried by carbonate minerals are liberated back at the surface via volcanism ${ }^{7}$; however, most is delivered to great mantle depths together with silicates ${ }^{8,9}$. Carbonate-silicate interaction along the subduction pressure-temperature $(\mathrm{P}-\mathrm{T})$ paths is particularly important because it not only influences the long-term carbon flux in subduction zones ${ }^{10}$ but also controls the isotopic systematics of coexisting carbonate and silicate that are ultimately recycled into the mantle. The latter in turn contributes fundamentally to the chemical and physical properties of the mantle $11-13$, for example, initiation of melting by lowering the mantle solidus, generation of alkalic magma in oceanic islands and carbonate metasomatism in cratonic mantle.

Magnesium $(\mathrm{Mg})$ and oxygen $(\mathrm{O})$ are two essential elements closely associated with carbon in carbonate minerals. Their isotopic compositions differ greatly from normal mantle rocks, that is, unaltered oceanic basalts and lherzolites have $\delta^{26} \mathrm{Mg}$ of $-0.25 \pm 0.07 \%$ (ref. 14) and $\delta^{18} \mathrm{O}$ of $+5.5 \pm 0.2 \%$ (ref. 15 ), whereas sedimentary carbonates have extremely light $\delta^{26} \mathrm{Mg}$ $\left(\right.$ down to $-6 \%$ ) ${ }^{16-18}$ and heavy $\delta^{18} \mathrm{O}$ (up to $+28 \%$ ) ${ }^{9,20}$. Thus, $\mathrm{Mg}-\mathrm{O}$ isotopic systematics can provide insight into carbonatesilicate chemical interactions during the subduction of carbonates and carbonated eclogites.

Here we present $\mathrm{Mg}, \mathrm{O}, \mathrm{C}$ and $\mathrm{Nd}$ isotopic data for a suite of ultrahigh pressure metamorphic (UHPM) marbles and enclosed carbonated eclogites from the Sulu orogen, east China. For comparison, we also report $\mathrm{Mg}$ isotopic data for Sinian sedimentary carbonates from the South China Block, and eclogites hosted in UHPM gneisses (termed as normal eclogites hereafter) from the Sulu orogen. Our results show that the carbonated eclogites have anomalously light $\delta^{26} \mathrm{Mg}$ and heavy $\delta^{18} \mathrm{O}$ as compared with the normal eclogites; moreover, UHPM marbles display negative correlation between $\delta^{26} \mathrm{Mg}$ and $\mathrm{MgO} / \mathrm{CaO}$. These $\mathrm{Mg}-\mathrm{O}$ isotopic characteristics reflect differential isotopic exchange between the marble and enclosed eclogite during subduction, and provide important constraints on deep carbon recycling.

\section{Results}

Geologic setting and samples. Triassic subduction of the South China Block beneath the North China Block resulted in the UHPM belts of Dabie and Sulu regions (Supplementary Fig. 1a $)^{21}$. Eclogites are widespread as pods, discontinuous layers or blocks in gneisses, ultramafic massifs and marbles. Previous studies suggest that these eclogites were formed by UHP metamorphism of Neoproterozoic basaltic rocks during the Triassic subduction of the South China Block ${ }^{21-24}$. Diamond and coesite inclusions present in eclogites and their country rocks indicate that they were in situ subducted and exhumed with peak metamorphic temperatures of $700-880^{\circ} \mathrm{C}$ and pressures up to $5.5 \mathrm{GPa}$ (refs 25-27). The marble masses in the Rongcheng area crop out as large-scale discontinuous lenses with lengths of more than $2,000 \mathrm{~m}$ and are surrounded by orthogneisses containing layers or lenses of eclogites, amphibolites and serpentinized peridotites (Supplementary Fig. 1b). Samples studied here were collected from local marble quarries where many eclogites are present as centimetre- to metre-sized lenticular or spherical blocks in host marbles (Supplementary Fig. 1c). These marblehosted eclogites are termed as carbonated eclogites hereafter. Field observation shows that the margins of carbonated eclogite blocks are invariably retrograded to amphibolites, while the cores are free of retrogression. The primary mineral assemblage of the carbonated eclogite is garnet, clinopyroxene, quartz, plagioclase and amphibole, with accessory minerals of calcite, dolomite, pyrrhotite, chalcopyrite and rutile (Supplementary Table 1). Garnet and pyroxene minerals in carbonated eclogites are enriched in $\mathrm{Ca}$ relative to those in normal eclogites because of the UHPM metasomatism by host marbles ${ }^{27}$. The marbles range from calcite-rich to dolomite-rich in composition, and consist mainly of calcite and dolomite with silicate mineral assemblage of
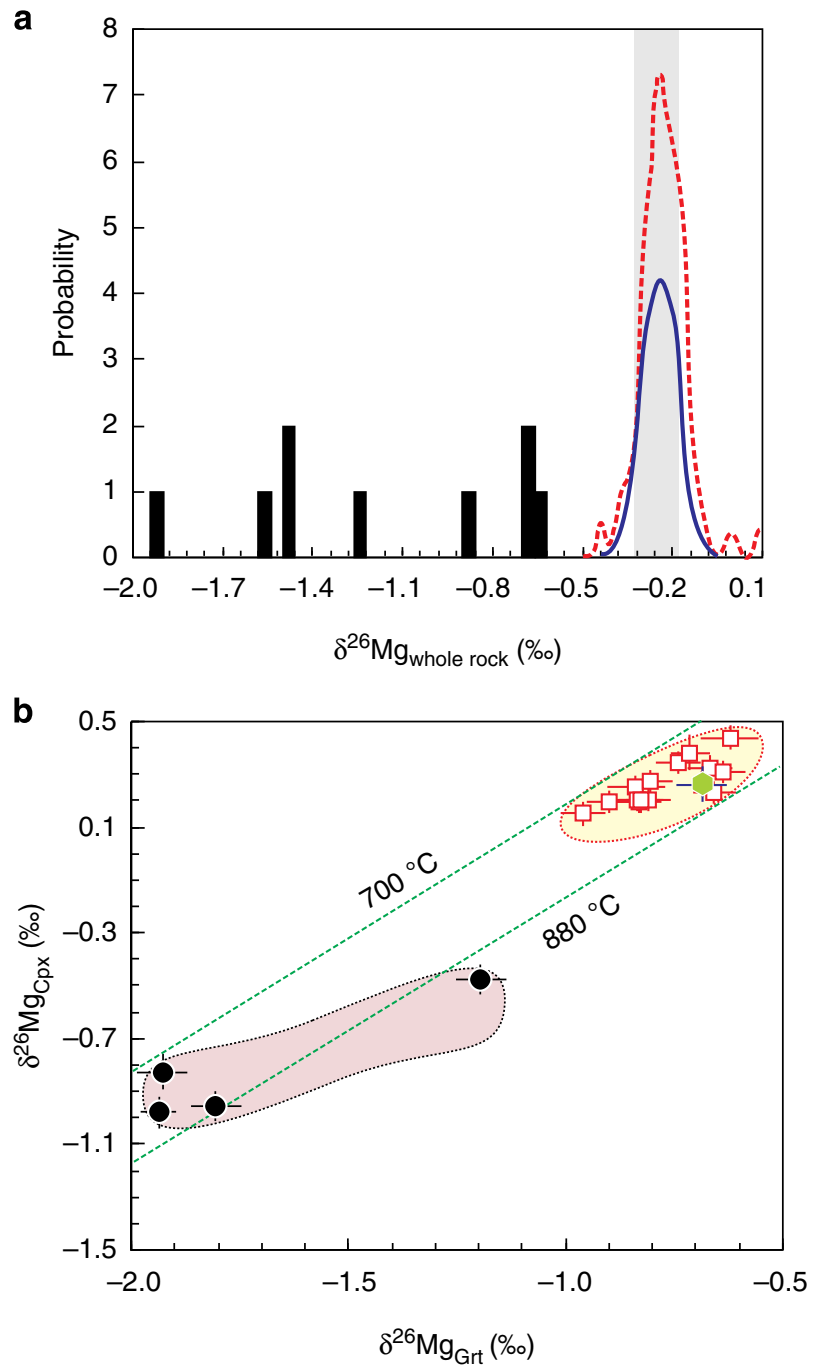

Figure 1 | Magnesium isotopic compositions of carbonated and normal eclogites. (a) Histogram of whole-rock $\delta^{26} \mathrm{Mg}$ of carbonated eclogites. The grey band represents the 'normal' mantle value ${ }^{14}$; the red dashed and blue solid curves are kernel density estimates of $\delta^{26} \mathrm{Mg}$ values of the normal eclogites from Sulu orogen and the Neoproterozoic basaltic protoliths from South China Block ${ }^{30}$, respectively. $\delta^{26} \mathrm{Mg}$ values of carbonated eclogites, represented by the histogram, are significantly lighter than both normal eclogites and their protoliths; (b) $\delta^{26} \mathrm{Mg}$ values of garnet $\left(\delta^{26} \mathrm{Mg}_{\mathrm{Grt}}\right)$ and pyroxene $\left(\delta^{26} M g_{C p x}\right)$ separates from the normal and carbonated eclogites. The green hexagon represents the mineral separates from a normal eclogite close to the UHPM marble in the Rongcheng area. The red squares are mineral separates from normal eclogites in Chinese Continental Scientific Drill (CCSD). The black circles represent the mineral separates from carbonated eclogites. Green dotted lines are the equilibrium garnetpyroxene $\mathrm{Mg}$ isotope fractionation lines ${ }^{51}$. Magnesium isotopic data are from Supplementary Tables 2-4. 
plagioclase, quartz and other minor phases such as pyroxene, amphibole, olivine and talc. Calcite contains significant $\mathrm{MgO}$ up to $4.43 w t . \%$, and dolomite has $\mathrm{MgO}$ in the range of $16.57 \sim 21.84 w t . \%$ (refs 28,29 ).

Magnesium isotopes. The $\delta^{26} \mathrm{Mg}$ values of normal eclogites vary from -0.440 to $+0.092 \%$, with an average value of $-0.224 \pm 0.048 \%$ o $(n=26$; Fig. 1a and Supplementary Table 2), similar to that of their Neoproterozoic basaltic protoliths $\left(\delta^{26} \mathrm{Mg}=-0.196 \pm 0.044 \% \text {; Fig. 1a }\right)^{30}$. Garnets from these normal eclogites are systemically lighter than coexisting pyroxenes $\left(\Delta^{26} \mathrm{Mg}_{\mathrm{Cpx}-\mathrm{Grt}}=\delta^{26} \mathrm{Mg}_{\mathrm{Cpx}}-\delta^{26} \mathrm{Mg}_{\mathrm{Grt}}=0.887-1.099 \%\right)$, with $\delta^{26} \mathrm{Mg}$ ranging from -0.943 to $-0.622 \%$ in garnets and from +0.151 to $+0.438 \%$ in pyroxenes (Fig. $1 \mathrm{~b}$ and Supplementary Table 2). By contrast, carbonated eclogites are highly depleted in ${ }^{26} \mathrm{Mg}$ as compared with the normal eclogites, with $\delta^{26} \mathrm{Mg}$ varying from -1.928 to $-0.648 \%$ (Fig. 1a and Supplementary Table 3). These Mg isotopic ratios are the lightest known values in silicate rocks. The amphibolitic margin $(11 \mathrm{RC}-2 \mathrm{E})$ and eclogitic core $(11 \mathrm{RC}-1)$ of an individual retrograded eclogite block (with diameter of $\sim 30 \mathrm{~cm}$ ) have $\delta^{26} \mathrm{Mg}$ of $-0.648 \%$ and $-0.684 \%$ (Supplementary Table 3 ), respectively. Garnet and pyroxene separates from carbonated eclogites also have the lightest $\delta^{26} \mathrm{Mg}$ values (Fig. $1 \mathrm{~b}$ and Supplementary Table 4 ), that is, from -1.937 to $-1.191 \%$ in garnet and from -0.980 to $-0.483 \%$ in pyroxene.

Sinian carbonates comprise limestone $(\mathrm{MgO} / \mathrm{CaO}=0.02)$ and dolostone $(\mathrm{MgO} / \mathrm{CaO}=0.62 \sim 0.73)$, with $\delta^{26} \mathrm{Mg}$ varying from -4.101 to $-2.396 \%$ in limestone and from -2.210 to $-1.009 \%$ in dolostone (Fig. 2a,b and Supplementary Table 3). The generally lighter $\delta^{26} \mathrm{Mg}$ in limestone than in dolostone is consistent with previous studies of normal sedimentary carbonates ${ }^{16-18}$. By contrast, $\delta^{26} \mathrm{Mg}$ values of the UHPM marbles vary from -2.508 to $-0.531 \%$ and form a negative correlation with the dolomite abundance and a positive correlation with the calcite abundance (Fig. 2c,d and Supplementary Table 3).

Oxygen and other isotopes. Two normal eclogites from Rongcheng have $\delta^{18} \mathrm{O}$ values of $+5.65 \%$ and $+3.96 \%$, respectively (Supplementary Table 3 ). The $\delta^{18} \mathrm{O}$ of carbonated eclogites span a range of +15.9 to $+21.1 \%$ o (Supplementary Table 3 ), which is consistent with previous studies of carbonated eclogites ${ }^{31}$. Neodymium isotope analyses of these carbonated eclogites yield initial $\varepsilon_{\mathrm{Nd}}$ of -12.3 to -1.1 (Supplementary Table 6), falling in the range of normal eclogites $\left(\varepsilon_{\mathrm{Nd}}=-16.7 \text { to }-0.1\right)^{32}$. The $\delta^{18} \mathrm{O}$ and $\delta^{13} \mathrm{C}$ of the UHPM marbles are in the ranges +20.3 to $+23.3 \%$ and -2.01 to $+4.77 \%$ (Supplementary Table 3 ), respectively, similar to those of their protoliths ${ }^{19,20}$.

\section{Discussion}

Garnet and pyroxene from both normal and carbonated eclogites reach $\mathrm{Mg}$ isotopic equilibrium at peak metamorphic temperatures of $700 \sim 880^{\circ} \mathrm{C}$ (Fig. 1b). The bulk carbonated eclogites and mineral separates have anomalously light $\delta^{26} \mathrm{Mg}$ and heavy $\delta^{18} \mathrm{O}$ values when compared with the normal eclogites and Neoproterozoic basaltic protoliths (Fig. 1a,b). Sedimentary limestones generally have lighter $\delta^{26} \mathrm{Mg}$ than dolostones ${ }^{16-18}$, whereas the UHPM marbles display the opposite trend, that is, isotopically heavy marbles have high $\mathrm{CaO}$ and low $\mathrm{MgO}$ contents (Fig. 2a,b). As such, the $\mathrm{Mg}-\mathrm{O}$ isotopic signatures preserved in the carbonated eclogites and UHPM marbles do not reflect their protolith heterogeneity, rather they reflect carbonate-
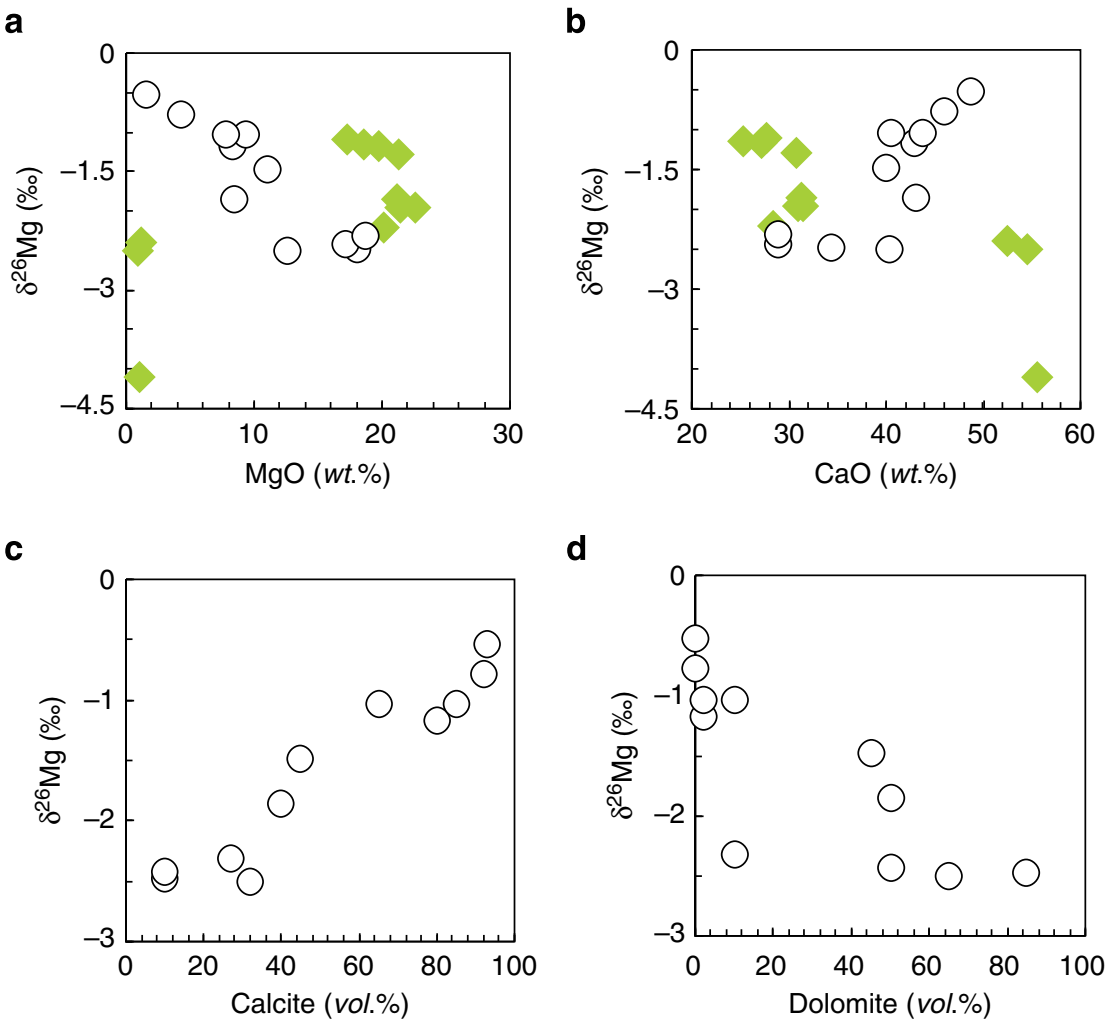

Figure 2 | Magnesium isotopic compositions of UHPM marbles and Sinian carbonates. (a) $\delta^{26} \mathrm{Mg}-\mathrm{MgO}$ variations of UHPM marbles and Sinian carbonates; (b) $\delta^{26} \mathrm{Mg}-\mathrm{CaO}$ variations of UHPM marbles and Sinian carbonates; (c) the variation of $\delta^{26} \mathrm{Mg}$ against calcite abundance in UHPM marbles; (d) the variation of $\delta^{26} \mathrm{Mg}$ against dolomite abundance in UHPM marbles. The white circles represent the UHPM marbles and the green diamonds represent the Sinian carbonates. Magnesium isotopic and major elemental data are from Supplementary Table 3; mineral abundances are from Supplementary Table 5. 


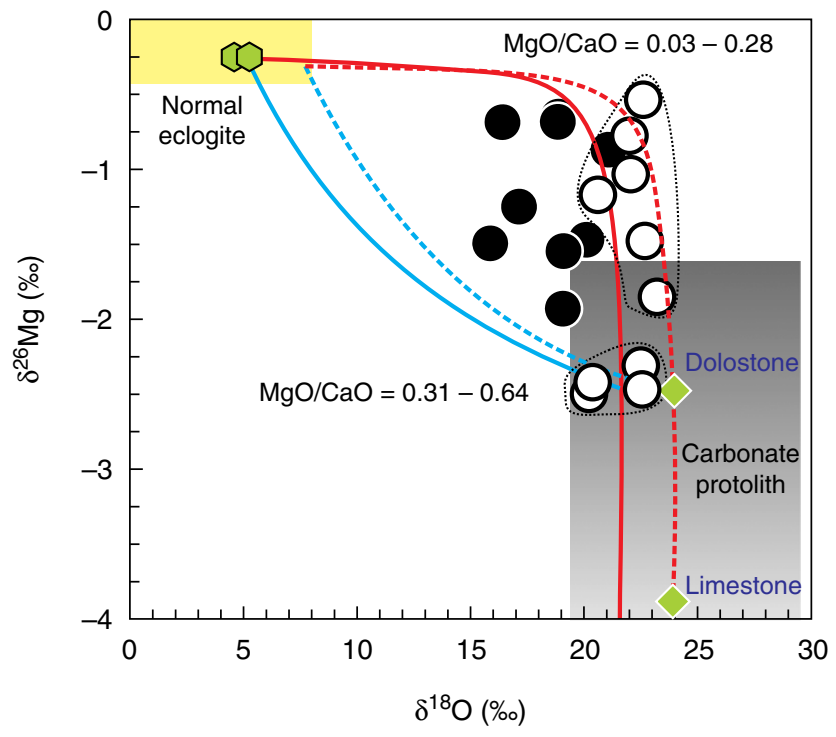

Figure 3 | Magnesium and 0 isotopic exchange between UHPM marbles and enclosed eclogites. The UHPM marbles and carbonated eclogites are represented by the white and black circles, respectively. Two end members of marble protoliths, limestone and dolostone are considered to have initial chemical compositions of $\mathrm{Mg}_{0.001} \mathrm{Ca}_{0.999} \mathrm{CO}_{3}$ and $\mathrm{Mg}_{0.5} \mathrm{Ca}_{0.5} \mathrm{CO}_{3}$, respectively. Their $\mathrm{O}$ and $\mathrm{Mg}$ isotopic compositions are: $\delta^{18} \mathrm{O}=+24 \%$ and $\delta^{26} \mathrm{Mg}=-4.00 \%$ for limestone, and $\delta^{18} \mathrm{O}=+24 \%$ and $\delta^{26} \mathrm{Mg}=-2.50 \%$ for dolostone. The eclogites are assumed to have initial $\delta^{18} \mathrm{O}$ of $+5.5 \%$, $\delta^{26} \mathrm{Mg}$ of $-0.25 \%$ and $\mathrm{MgO}=8 \mathrm{wt}$. $\%$. The green hexagons represent two normal eclogites in gneisses close to the UHPM marble in the Rongcheng area. Equations that govern the isotopic exchange model are given in Supplementary Note 1. The red and blue curves represent the isotopic exchange of normal eclogites with limestone and with dolostone, respectively. The solid curves represent the $\mathrm{Mg}-\mathrm{O}$ isotopic evolution of eclogites and the dashed curves represent the $\mathrm{Mg}-\mathrm{O}$ isotopic evolution of marbles by isotopic exchange. The $\delta^{18} \mathrm{O}$ ranges of Sinian carbonates $^{19}$ and normal eclogites ${ }^{23}$ are shown for comparison.

Magnesium and $\mathrm{O}$ isotopic data are from Supplementary Tables 2 and 3.

eclogite interactions during subduction including carbonateeclogite mixing, metamorphic dehydration or rehydration, decarbonation and isotopic exchange.

Carbonates are known to have extremely heavy $\delta^{18} \mathrm{O}$ and light $\delta^{26} \mathrm{Mg}$ values ${ }^{16-20}$; thus, carbonate-eclogite mixing might explain the bulk Mg-O isotopic characteristics of carbonated eclogites. If we assume that eclogite lenses in marbles have initial $\delta^{26} \mathrm{Mg}$ and $\delta^{18} \mathrm{O}$ values similar to the normal eclogites, then a mixing calculation with carbonates indicates that $\sim 60-90 \%$ contribution by carbonate is required to fit the bulk $\mathrm{Mg}-\mathrm{O}$ isotopic compositions. However, the low $\mathrm{CO}_{2}$ contents of carbonated eclogites (0.11-6.43wt.\%; Supplementary Table 3 ) imply that the calculated carbonate proportion is unrealistically high. In addition, carbonate-eclogite mixing predicts lighter $\delta^{26} \mathrm{Mg}$ values in those samples containing higher $\mathrm{CO}_{2}$ contents, which is not seen in the carbonated eclogites (Supplementary Fig. 2). Most importantly, garnet and pyroxene minerals in carbonated eclogites are equally enriched in ${ }^{24} \mathrm{Mg}$ and ${ }^{18} \mathrm{O}$. This requires a chemical exchange rather than simple physical mixing between eclogite lenses and marbles.

The $\mathrm{Mg}$ and $\mathrm{O}$ isotope fractionations between carbonated eclogites and their protoliths are far greater than predicted by closed-system metamorphic dehydration ${ }^{30,33}$. In addition, the $\delta^{26} \mathrm{Mg}$ of low $\mathrm{MgO} / \mathrm{CaO}$ marbles are significantly heavier than the values of their pre-metamorphosed counterpart, Sinian

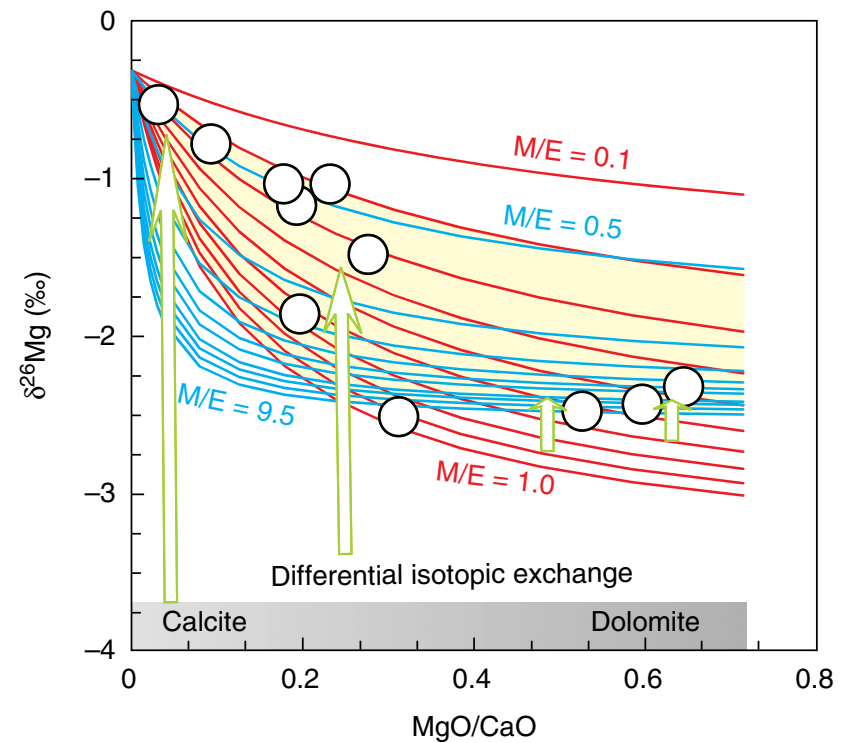

Figure 4 | Differential isotopic exchanges of eclogites with calcite-rich and dolomite-rich marbles. The eclogites are assumed to have initial $\delta^{26} \mathrm{Mg}$ of $-0.25 \%$ and $\mathrm{MgO}=8 \mathrm{wt} . \%$. Equations that govern differential isotopic exchange model are given in the Supplementary Note 2. At a given weighted ratio of carbonate to eclogite (M/E) during isotopic exchange, marbles with different compositions (limestone versus dolostone) shift their $\delta^{26} \mathrm{Mg}$ in different degrees (shown by arrows). The red and blue curves assume that the initial $\delta^{26} \mathrm{Mg}$ of carbonates are $-4.00 \%$ and $-2.50 \%$, respectively. Different curves represent the isotopic exchange under different $M / E$ ratios. The increment of $M / E$ ratio is 0.1 for the red and 1.0 for the blue. Data are from Supplementary Table 3.

limestones (Fig. 2a,b), which is opposite to the direction of isotope fractionation induced by metamorphic dehydration ${ }^{34}$. Thus, closed-system metamorphic dehydration is unlikely to account for the observed $\mathrm{Mg}-\mathrm{O}$ isotopic variations in carbonated eclogites and UHPM marbles. Although the retrograded amphibolitic rim of an individual carbonated eclogite block has higher alkalies and $\mathrm{CO}_{2}$ relative to the eclogitic core, they have similar $\mathrm{Mg}$ isotopic compositions (Supplementary Table 3), ruling out the possibility of retrogression-induced $\mathrm{Mg}$ isotope fractionation.

Metamorphic decarbonation involves the decomposition of a substantial amount of carbonate minerals by incorporating $\mathrm{Mg}$ and $\mathrm{Ca}$ oxides into the silicates and releasing $\mathrm{CO}_{2}$ (ref. 35). This may explain the light $\delta^{26} \mathrm{Mg}$ and heavy $\delta^{18} \mathrm{O}$ of silicate minerals in carbonated eclogites. However, metamorphic decarbonation cannot significantly fractionate $\mathrm{Mg}$ isotopes, neither can it form the $\delta^{26} \mathrm{Mg}-\mathrm{CaO}$ and $\delta^{26} \mathrm{Mg}-\mathrm{MgO}$ correlations in UHMP marbles (Fig. 2a,b). Furthermore, previous studies have revealed that the subduction P-T trajectory of these carbonated eclogites and UHPM marbles does not intersect with experimentally determined carbonate-out boundaries (Supplementary Fig. 3) ${ }^{8}$, suggesting limited decarbonation of these UHPM marbles. This is further supported by the similar $\mathrm{O}$ and $\mathrm{C}$ isotopic compositions between Sinian carbonates and UHPM marbles (Supplementary Fig. 4), as large $\mathrm{O}$ and $\mathrm{C}$ isotope fractionations are expected during decarbonation ${ }^{36}$.

The most likely process causing the $\mathrm{Mg}$ and $\mathrm{O}$ isotopic variations in carbonated eclogites and UHPM marbles is thus through fluid-mediated isotopic exchange. Previous studies revealed that $\mathrm{Mg}$ isotope fractionation between silicate and carbonate decreases dramatically from low temperatures $(\geq 2 \%$ o at $\left.T<300{ }^{\circ} \mathrm{C}\right)$ to high temperatures $(0.05 \sim 0.08 \%$ at $T=600$ 
$\left.\sim 800^{\circ} \mathrm{C}\right)^{37-40}$. Similar is true for $\mathrm{O}$ isotopes ${ }^{33}$. Therefore, extensive isotopic exchanges between marbles and eclogites are expected during prograde metamorphism to reduce their $\mathrm{Mg}$ and $\mathrm{O}$ isotopic differences. Assuming that sedimentary limestone and dolostone have heavy $\delta^{18} \mathrm{O}$ of $+24 \%$ (ref. 19) but light $\delta^{26} \mathrm{Mg}$ around $-4.00 \%$ and $-2.50 \%$ (refs $16-18$ ), respectively, and eclogite lenses in carbonates have initial $\mathrm{Mg}$ and $\mathrm{O}$ isotopic compositions similar to the normal eclogites (with average $\delta^{18} \mathrm{O}=+5.5 \%$ and $\delta^{26} \mathrm{Mg}=-0.25 \%$ ), the eclogites would become depleted in ${ }^{26} \mathrm{Mg}$ and enriched in ${ }^{18} \mathrm{O}$ after UHP isotopic exchange with the marbles (Fig. 3). Magnesium isotopic exchange also elevated the $\delta^{26} \mathrm{Mg}$ values of UHPM marbles in various degrees (Fig. 3). As limestone contains significantly lower $\mathrm{Mg}$ than dolostone, at a given weighted ratio between marble and eclogite the limestone is more susceptible than dolostone to $\mathrm{Mg}$ isotopic exchange with the eclogites (Fig. 3). Consequently, the calcite-rich carbonates exhibit a large shift in $\delta^{26} \mathrm{Mg}$ towards heavier values, whereas the dolomite-rich carbonates tend to preserve their initial $\delta^{26} \mathrm{Mg}$ values (Fig. 4). The negative covariation of $\delta^{26} \mathrm{Mg}$ versus $\mathrm{MgO} / \mathrm{CaO}$ for UHPM marbles (Fig. 4) is therefore produced by the differential $\mathrm{Mg}$ isotopic exchange of compositionally varied carbonates with enclosed eclogite lenses.

Sedimentary carbonates are the main light $-\delta^{26} \mathrm{Mg}$ sink of Earth's reservoirs ${ }^{18}$. Recycling of carbonates into the mantle has the potential to cause local mantle $\mathrm{Mg}$ isotope heterogeneity ${ }^{41}$. Knowledge of whether $\mathrm{Mg}$ isotopic compositions of sedimentary carbonates can be preserved during crustal subduction is fundamental to quantifying the amount of recycled carbonate in mantle sources using $\mathrm{Mg}$ isotopes. Our study suggests that calcite-rich carbonates are highly unlikely to retain their initial light $\delta^{26} \mathrm{Mg}$ but become isotopically heavier towards the value of silicates, whereas dolomite-rich carbonates are more capable of preserving their initial values. On the other hand, the carbonated silicates (for example, eclogites) gain light $\delta^{26} \mathrm{Mg}$ values that are significantly different from other normal eclogites and ambient mantle. These silicates may produce significant light $-\delta^{26} \mathrm{Mg}$ components in the mantle, as sampled by cratonic eclogites ${ }^{42}$ and highly metasomatized peridotite xenoliths ${ }^{43}$.

\section{Methods}

Magnesium isotopic analyses. Magnesium isotopic analyses were carried out at the Isotope Laboratory of the University of Arkansas, Fayetteville, USA. Wholerock powders of eclogites and carbonates, and the mineral separates were digested using Optima-grade mixed acid of $\mathrm{HF}-\mathrm{HNO}_{3}-\mathrm{HCl}$. After complete dissolution, dried residues from carbonate solutions were added $12 \mathrm{~N} \mathrm{HCl}$, and those from silicate solutions were taken up in $1 \mathrm{~N} \mathrm{HNO}_{3}$ for ion column chemistry. Detail column chemistry procedures have been reported elsewhere 44,45

Chemical separation and purification of $\mathrm{Mg}$ were achieved by cation exchange chromatography with Bio-Rad AG50W-X8 resin in $1 \mathrm{~N} \mathrm{HNO}_{3}$ media. Additional chromatographic step was processed for the carbonate to further separate $\mathrm{Mg}$ from $\mathrm{Ca}$ by using Bio-Rad 200-400 mesh AG50W-X12 resin in $12 \mathrm{~N} \mathrm{HCl}$ media. The same column procedure was performed twice in order to obtain the pure $\mathrm{Mg}$ recovery. The pure $\mathrm{Mg}$ solutions of silicate and carbonate were then dried down and re-dissolved in $3 \% \mathrm{HNO}_{3}$ ready for mass spectrometry.

The $\mathrm{Mg}$ isotopic compositions were analysed by the sample-standard bracketing method using a $\mathrm{Nu}$ Plasma MC-ICPMS at low-resolution mode ${ }^{46}$. Each batch of sample analysis contains at least one well-characterized standard. Sample solution was repeated on ratio measurements for more than four times within a session. The long-term precision is better than $\pm 0.07 \%$ ( 2 s.d.) for the ${ }^{26} \mathrm{Mg} /{ }^{24} \mathrm{Mg}$ ratio. Magnesium isotopic results are reported in the conventional $\delta$ notation in per mil relative to DSM-3, $\delta^{26} \mathrm{Mg}=\left[\left({ }^{26} \mathrm{Mg} /{ }^{24} \mathrm{Mg}\right)_{\text {sample }} /\left({ }^{26} \mathrm{Mg} /{ }^{24} \mathrm{Mg}\right)_{\mathrm{DSM}-3}-1\right] \times 1,000$.

Oxygen-carbon and neodymium isotopic analyses. Oxygen and carbon isotopic analyses were conducted at the CAS Key Laboratory of Crust-mantle Materials and Environments in the University of Science and Technology of China, Hefei. Oxygen isotopes of eclogites were measured by the laser fluorination technique. The $\mathrm{O}_{2}$ was extracted by a $\mathrm{CO}_{2}$ laser and transferred to a Finigan Delta + mass spectrometer for the measurement of ${ }^{18} \mathrm{O} /{ }^{16} \mathrm{O}$ and ${ }^{17} \mathrm{O} /{ }^{16} \mathrm{O}$ ratios. The $\mathrm{O}$ and $\mathrm{C}$ isotopes of carbonates were analysed by the GasBench II technique in the continuous flow mode and the extracted $\mathrm{CO}_{2}$ gases were measured on a Finnigan MAT253 mass spectrometer. Detail procedures are described previously ${ }^{47}$. The
$\mathrm{O}$ and $\mathrm{C}$ isotopic results are reported in the $\delta$ notation in per mil relative to Vienna Standard Mean Ocean Water and Vienna Peedee Belemnite, respectively.

Samarium-Nd isotopic analyses were performed using an IsoProbe-T thermal ionization mass spectrometer at the State Key Laboratory of Lithospheric Evolution, Institute of Geology and Geophysics, Chinese Academy of Sciences. Samarium isotopes were measured using single Ta filament. Neodymium isotopes were determined using single tungsten filament with $\mathrm{TaF}_{5}$ as an ionization activator. Detail column chemistry and mass spectrometer operation condition have been described previously ${ }^{48} .{ }^{143} \mathrm{Nd} /{ }^{144} \mathrm{Nd}$ ratios were corrected for mass fractionation using ${ }^{146} \mathrm{Nd} /{ }^{144} \mathrm{Nd}=0.7219$. During the period of data collection, the measured value for the JNdi-Nd standard was $0.512117 \pm 10$ (2 s.d.).

Whole-rock chemistry and mineral abundances. Major elements (except FeO, $\mathrm{H}_{2} \mathrm{O}^{+}$and $\mathrm{CO}_{2}$ ) were analysed at the Hebei Institute of Regional Geology and Mineral Resources, China, by wavelength dispersive X-Ray fluorescence spectrometry ${ }^{49}$. The analytical uncertainties are better than $1 \%$. The FeO contents of the samples were determined by conventional wet chemical method ${ }^{50}$. After the quantitative oxidation of $\mathrm{Fe}^{2+}$ to $\mathrm{Fe}^{3+}$, the ferrous iron is regenerated by backtitration with ammonium ferrous sulfate. Then, the original $\mathrm{Fe}^{2+}$ content can be calculated. $\mathrm{H}_{2} \mathrm{O}^{+}$and $\mathrm{CO}_{2}$ were determined by gravimetric methods and potentiometry, respectively. The relative abundances of carbonate minerals were determined by X-ray diffraction using a Rigaku Smart lab $(9 \mathrm{~kW})$ at the China University of Geosciences, Beijing. The X-ray source was a $\mathrm{Cu}$ anode operated at $45 \mathrm{kV}$ and $200 \mathrm{~mA}$ using $\mathrm{CuK} \alpha_{1}$ radiation equipped with a diffracted beam graphite monochromator.

\section{References}

1. Dasgupta, R. \& Hirschmann, M. M. The deep carbon cycle and melting in Earth's interior. Earth Planet Sci. Lett. 298, 1-13 (2010).

2. Huybers, P. \& Langmuir, C. Feedback between deglaciation, volcanism, and atmospheric $\mathrm{CO}_{2}$. Earth Planet Sci. Lett. 286, 479-491 (2009).

3. Yaxley, G. M. \& Green, D. H. Experimental demonstration of refractory carbonate-bearing eclogite and siliceous melt in the subduction regime. Earth Planet Sci. Lett. 128, 313-325 (1994).

4. Hammouda, T. High-pressure melting of carbonated eclogite and experimental constraints on carbon recycling and storage in the mantle. Earth Planet Sci. Lett. 214, 357-368 (2003).

5. Dasgupta, R., Hirschmann, M. M. \& Withers, A. C. Deep global cycling of carbon constrained by the solidus of anhydrous, carbonated eclogite under upper mantle conditions. Earth Planet Sci. Lett. 227, 73-85 (2004)

6. Connolly, J. Computation of phase equilibria by linear programming: a tool for geodynamic modeling and its application to subduction zone decarbonation. Earth Planet Sci. Lett. 236, 524-541 (2005).

7. Burton, M. R., Sawyer, G. M. \& Granieri, D. Deep carbon emissions from volcanoes. Rev. Mineral Geochem. 75, 323-354 (2013).

8. Dasgupta, R. Ingassing, storage, and outgassing of terrestrial carbon through geologic time. Rev. Mineral Geochem. 75, 183-229 (2013).

9. Galvez, M. E. et al. Graphite formation by carbonate reduction during subduction. Nat. Geosci. 6, 473-477 (2013).

10. Ague, J. J. \& Nicolescu, S. Carbon dioxide released from subduction zones by fluid-mediated reactions. Nat. Geosci. 7, 355-360 (2014).

11. Dasgupta, R. \& Hirschmann, M. M. Melting in the Earth's deep upper mantle caused by carbon dioxide. Nature 440, 659-662 (2006)

12. Huang, S., Farkaš, J. \& Jacobsen, S. B. Stable calcium isotopic compositions of Hawaiian shield lavas: evidence for recycling of ancient marine carbonates into the mantle. Geochim. Cosmochim. Acta 75, 4987-4997 (2011).

13. Kiseeva, E. S. et al. An experimental study of carbonated eclogite at $3 \cdot 5-5 \cdot 5 \mathrm{GPa}$-implications for silicate and carbonate metasomatism in the cratonic mantle. J. Petrol. 53, 727-759 (2012).

14. Teng, F.-Z. et al. Magnesium isotopic composition of the Earth and chondrites Geochim. Cosmochim. Acta 74, 4150-4166 (2010).

15. Eiler, J. M. Oxygen isotope variations of basaltic lavas and upper mantle rocks. Rev. Mineral. Geochem. 43, 319-364 (2001).

16. Galy, A., Bar-Matthews, M., Halicz, L. \& O’Nions, R. K. Mg isotopic composition of carbonate: insight from speleothem formation. Earth Planet Sci. Lett. 201, 105-115 (2002).

17. Wombacher, F. et al. Magnesium stable isotope fractionation in marine biogenic calcite and aragonite. Geochim. Cosmochim. Acta 75, 5797-5818 (2011).

18. Young, E. D. \& Galy, A. The isotope geochemistry and cosmochemistry of magnesium. Rev. Mineral. Geochem. 55, 197-230 (2004).

19. Lambert, I., Walter, M., Wenlong, Z., Songnian, L. \& Guogan, M. Palaeoenvironment and carbon isotope stratigraphy of upper Proterozoic carbonates of the Yangtze platform. Nature 325, 140-142 (1987).

20. Schidlowski, M., Eichmann, R. \& Junge, C. E. Precambrian sedimentary carbonates: carbon and oxygen isotope geochemistry and implications for the terrestrial oxygen budget. Precambrian Res. 2, 1-69 (1975). 
21. Li, S. et al. Collision of the North China and Yangtse Blocks and formation of coesite-bearing eclogites: timing and processes. Chem. Geol. 109, 89-111 (1993).

22. Zheng, Y.-F. et al. Zircon U-Pb age, $\mathrm{Hf}$ and $\mathrm{O}$ isotope constraints on protolith origin of ultrahigh-pressure eclogite and gneiss in the Dabie orogen. Chem. Geol. 231, 135-158 (2006).

23. Zheng, Y.-F., Fu, B., Gong, B. \& Li, L. Stable isotope geochemistry of ultrahigh pressure metamorphic rocks from the Dabie-Sulu orogen in China: implications for geodynamics and fluid regime. Earth Sci. Rev. 62, 105-161 (2003).

24. Liu, F. \& Liou, J. Zircon as the best mineral for P-T-time history of UHP metamorphism: A review on mineral inclusions and U-Pb SHRIMP ages of zircons from the Dabie-Sulu UHP rocks. J. Asian Earth Sci. 40, 1-39 (2011).

25. Xu, S. et al. Diamond from the Dabie Shan metamorphic rocks and its implication for tectonic setting. Science 256, 80-82 (1992).

26. Ye, K., Cong, B. \& Ye, D. The possible subduction of continental material to depths greater than $200 \mathrm{~km}$. Nature 407, 734-736 (2000).

27. Kato, T., Enami, M. \& Zhai, M. Ultra-high-pressure (UHP) marble and eclogite in the Su-Lu UHP terrane, eastern China. J. Metamorph. Geol. 15, 169-182 (1997).

28. Ye, K. \& Hirajima, T. High-pressure marble at Yangguantun, Rongcheng county, Shandong province, eastern China. Mineral. Petrol. 57, 151-165 (1996).

29. Ogasawara, Y., Zhang, R. \& Liou, J. Petrogenesis of dolomitic marbles from Rongcheng in the Su-Lu ultrahigh-pressure metamorphic terrane, eastern China. Island Arc. 7, 82-97 (1998).

30. Wang, S.-J., Teng, F.-Z., Li, S.-G. \& Hong, J.-A. Magnesium isotopic systematics of mafic rocks during continental subduction. Geochim. Cosmochim. Acta. 10.1016/j.gca.2014.03.029 (2014).

31. Chu, X., Guo, J., Fan, H. \& Jin, C. Oxygen isotope compositions of eclogites in Rongcheng, Eastern China. Chin. Sci. Bull. 48, 372-378 (2003).

32. Jahn, B. in When Continents Collide: Geodynamics and Geochemistry of Ultrahigh-Pressure Rocks Vol. 10 (eds Hacker, B. R. \& Liou, J. G.) 203-239 (Kluwer Academic Publishers, 1998).

33. Matthews, A. Oxygen isotope geothermometers for metamorphic rocks. J. Metamorph. Geol. 12, 211-219 (1994).

34. Li, W., Chakraborty, S., Beard, B. L., Romanek, C. S. \& Johnson, C. M. Magnesium isotope fractionation during precipitation of inorganic calcite under laboratory conditions. Earth Planet Sci. Lett. 333, 304-316 (2012).

35. Knoche, R., Sweeney, R. J. \& Luth, R. W. Carbonation and decarbonation of eclogites: the role of garnet. Contrib. Mineral Petrol 135, 332-339 (1999).

36. Valley, J. W. Stable isotope geochemistry of metamorphic rocks. Rev. Mineral. Geochem. 16, 445-489 (1986).

37. Tipper, E. et al. The magnesium isotope budget of the modern ocean: Constraints from riverine magnesium isotope ratios. Earth Planet Sci. Lett. 250, 241-253 (2006).

38. Immenhauser, A. et al. Magnesium-isotope fractionation during low-Mg calcite precipitation in a limestone cave-Field study and experiments. Geochim. Cosmochim. Acta 74, 4346-4364 (2010).

39. Higgins, J. A. \& Schrag, D. P. Constraining magnesium cycling in marine sediments using magnesium isotopes. Geochim. Cosmochim. Acta 74, 5039-5053 (2010).

40. Macris, C. A., Young, E. D. \& Manning, C. E. Experimental determination of equilibrium magnesium isotope fractionation between spinel, forsterite, and magnesite from $600^{\circ} \mathrm{C}$ to $800^{\circ}$ C. Geochim. Cosmochim. Acta 118, 18-32 (2013).

41. Yang, W., Teng, F.-Z., Zhang, H.-F. \& Li, S.-G. Magnesium isotopic systematics of continental basalts from the North China craton: Implications for tracing subducted carbonate in the mantle. Chem. Geol. 328, 185-194 (2012).
42. Wang, S.-J., Teng, F.-Z., Williams, H. M. \& Li, S.-G. Magnesium isotopic variations in cratonic eclogites: origins and implications. Earth Planet Sci. Lett. 359, 219-226 (2012).

43. Xiao, Y., Teng, F.-Z., Zhang, H.-F. \& Yang, W. Large magnesium isotope fractionation in peridotite xenoliths from eastern North China craton: product of melt-rock interaction. Geochim. Cosmochim. Acta 115, 241-261 (2013).

44. Yang, W., Teng, F.-Z. \& Zhang, H.-F. Chondritic magnesium isotopic composition of the terrestrial mantle: a case study of peridotite xenoliths from the North China craton. Earth Planet Sci. Lett. 288, 475-482 (2009).

45. Ling, M.-X. et al. Formation of the world's largest REE deposit through protracted fluxing of carbonatite by subduction-derived fluids. Sci. Rep. 3 (2013).

46. Teng, F. Z. \& Yang, W. Comparison of factors affecting the accuracy of high-precision magnesium isotope analysis by multi-collector inductively coupled plasma mass spectrometry. Rapid Commun. Mass Spectrom. 28, 19-24 (2014).

47. Zha, X. P., Zhao, Y. Y. \& Zheng, Y. F. An online method combining a Gasbench II with continuous flow isotope ratio mass spectrometry to determine the content and isotopic compositions of minor amounts of carbonate in silicate rocks. Rapid Commun. Mass Spectrom. 24, 2217-2226 (2010).

48. Chu, Z.-Y. et al. Evaluation of sample dissolution method for Sm-Nd isotopic analysis of scheelite. J. Anal. At. Spectrom. 27, 509-515 (2012).

49. Gao, S. et al. Silurian-Devonian provenance changes of South Qinling basins: implications for accretion of the Yangtze (South China) to the North China cratons. Tectonophysics 250, 183-197 (1995).

50. Wilson, A. The micro-determination of ferrous iron in silicate minerals by a volumetric and a colorimetric method. Analyst 85, 823-827 (1960).

51. Huang, F., Chen, L., Wu, Z. \& Wang, W. First-principles calculations of equilibrium $\mathrm{Mg}$ isotope fractionations between garnet, clinopyroxene, orthopyroxene, and olivine: Implications for Mg isotope thermometry. Earth Planet Sci. Lett. 367, 61-70 (2013).

\section{Acknowledgements}

We would like to thank Y.-F. Zheng for support on oxygen isotopic analysis and for thoughtful discussion, Z.-Z. Han, S.-C. An, H.-M. Zhang and J.-A. Hong for field works, H.-O. Gu and W.-Y. Li for help in the clean lab. The work is supported by the National Science Foundation (EAR-0838227, EAR-1056713 and EAR1340160) to F.-Z.T. and the National Nature Scientific Foundation of China (No. 41230209, 41090372) to S.-G.L.

\section{Author contributions}

S.-J.W., F.-Z.T. and S.-G.L. designed the study, interpreted the data and wrote the paper. S.-J.W carried out all the laboratory work. All authors contributed equally to this work.

\section{Additional information}

Supplementary Information accompanies this paper at http://www.nature.com/ naturecommunications

Competing financial interests: The authors declare no competing financial interests

Reprints and permission information is available online at http://npg.nature.com/ reprintsandpermissions/

How to cite this article: Wang, S.-J. et al. Tracing carbonate-silicate interaction during subduction using magnesium and oxygen isotopes. Nat. Commun. 5:5328 doi: $10.1038 /$ ncomms6328 (2014). 